\title{
TATACARA PEMERIKSAAN PERMOHONAN DISPENSASI KAWIN MENURUT PERMA NOMOR 5 TAHUN 2019 \\ (Analisis Putusan No.0017/Pdt.P/2020/PA.Lpk)
}

\author{
Muhammad Syukri \\ Albani Nasution \\ Fakultas Syariah dan \\ Hukum UIN Sumatera \\ Utara \\ syukrialbani@uinsu.ac.id
}

\section{Ali Akbar \\ Fakultas Syariah dan Hukum UIN Sumatera Utara \\ Aliakbar@uinsu.ac.id}

\section{Maimunah Siagian}

Fakultas Syariah dan Hukum UIN Sumatera Utara

Maimunahsiagian@uinsu.a c.id

\begin{abstract}
Children have the right to choose, whether to marry or not, and when their choice falls to marry, then the biggest thing to be considered is the age, the age that is considered safe and permissible for marriage, from a health perspective, from a psychological perspective, as well as from an economic standpoint. This study aims to see how the judges consideration in deciding marriage dispensation cases, based on the analysis of the judge's decision No.0017/ Pdt.P / 2020 / PA.Lpk. The method used in this research is normative juridical. Indonesia as a State party to the Convention on the rights of the child (Convention on the rights of children) assert, that all actions concerning children undertaken by institutions, social welfare institutions, state or private, courts, administrative authorities or legislative bodies, are implemented in the best interest of the child, to provide protection for children who choose to marry while they are hindered by age.
\end{abstract}

Keywords: Examination Procedure, Marriage Dispensation Application, Perma.

\begin{abstract}
Abstrak: Anak merupakan amanah dan karunia Tuhan Yang Maha Esa yang memiliki harkat dan martabat sebagai manusia seutuhnya serta memiliki hak yang sama untuk tumbuh dan berkembang. Anak memiliki hak untuk memilih, antara menikah atau tidak, dan ketika pilihan mereka jatuh kepada menikah, maka hal yang paling besar untuk menjadi pertimbangan adalah umur, umur yang dianggap aman dan boleh untuk melangsungkan pernikahan, di pandang aman dari sisi kesehatan, dari sisi psikologis, maupun dari dari sisi ekonomi. Penelitian ini bertujuan untuk melihat
\end{abstract}


bagaimana pertimbangan yang dilakukan hakim dalam memutuskan perkara dispensasi nikah, berdasarkan analisis putusan hakim No.0017/Pdt.P/2020/PA.Lpk. Metode yang digunakan dalam penelitian adalah dengan menggunakan yuridif normatif. Indonesia sebagai Negara pihak dalam Convention on the Rights of the Child (Konvensi tentang Hak-hak Anak) menegaskan, bahwa semua tindakan mengenai anak yang dilakukan oleh lembaga, baik lembaga kesejahteraan sosial, negara atau swasta, pengadilan, penguasa administratif atau badan legislatif, dilaksanakan demi kepentingan terbaik anak, memberikan perlindungan terhadap anak yang memilih untuk menikah sementara dia terhalang oleh umur.

Kata Kunci: Tatacara Pemeriksaan, Permohonan dispensasi kawin, Perma

\section{Pendahuluan}

Untuk mengantisipasi disparitas penanganan perkara permohonan dispensasi kawin, karena peraturan perundangundangan belum mengatur secara tegas dan rinci tentang proses mengadili perkara dispensasi kawin, maka Mahkamah Agung RI menerbitkan Peraturan Mahkamah Agung RI Nomor 5 Tahun 2019 Tentang Pedoman Mengadili Permohonan Dispensasi Kawin (selanjutnya disebut Perma Dispensasi Kawin). Perma tersebut menetapkan bahwa hakim mengadili perkara dispensasi kawin berdasarkan asas:

1. Kepentingan terbaik bagi anak;

2. Hak hidup dan tumbuh kembang anak;

3. Penghargaan atas pendapat anak;

4. Penghargaan atas harkat dan martabat manusia;

5. Non-diskriminasi;

6. Kesetaraan gender;

7. Persamaan di depan hukum;

8. Keadilan;

9. Kemanfaatan; dan

10. Kepastian hukum. 
Mahkamah Agung merespon dengan cepat Revisi UUP dengan menerbitkan Perma Dispensasi Kawin guna mewujudkan pemeriksaan perkara dispensasi kawin yang berorientasi kepentingan anak dengan mepertimbangkan aspek moral, agama, adat dan budaya, aspek psikologis, aspek kesehatan, dan dampak yang ditimbulkan.

Pernikahan dini (di bawah umur) merupakan praktik pernikahan yang dilakukan oleh pasangan yang salah satu atau berusia masih muda dalam pandangan kekinian. Praktik pernikahan ini dipandang perlu memperoleh perhatian dan pengaturan yang jelas. Maka, selain usia minimum pernikahan ditetapkan, beberapa negara mengatur cara untuk mengantisipasai masih mungkinnya pernikahan seperti itu bisa dilaksanakan, antara lain, aturan yang memberikan keringanan (dipensasi).1

Di antara persyaratan perkawinan yang berlaku di Indonesia, menurut Undang-Undang Nomor 1 Tahun 1974 Tentang Perkawinan (selanjutnya disebut UUP) yang telah diubah dengan Undang-Undang Nomor 16 Tahun 2019 Tentang Perubahan Atas Undang-Undang Nomor 1 Tahun 1974 Tentang Perkawinan (selanjutnya disebut Revisi UUP) adalah berkaitan dengan usia perkawinan, calon mempelai, baik pria maupun wanita telah mencapai usia 19 (sembilan belas) tahun.

Berdasarkan ketentuan Pasal 7 ayat (2) UUP, jika terjadi penyimpangan dari persyaratan usia perkawinan tersebut di atas, maka perkawinan baru dapat dilangsungkan setelah mendapat dispensasi dari pengadilan. Orang tua atau wali calon mempelai laki-laki dan/atau wanita yang belum mencapai usia perkawinan mengajukan permohonan dispensasi kawin ke pengadilan, Pengadilan Agama bagi yang beragama Islam dan pengadilan Negeri bagi yang beragama lain.

1 Asep Saepudin Jahar,Dkk, Hukum Keluarga Pidana \& Bisnis, (Jakarta: Kencana Prenadamedia Group, 2013), 43. 
Dalam Pasal (2) dan (3) Revisi UUP disebutkan bahwa orang tua atau wali calon mempelai laki-laki dan/atau wanita dapat mengajukan permohonan dispensasi kawin ke pengadilan didasarkan alasan mendesak disertai dengan bukti-bukti pendukung yang cukup. Setelah mendengarkan pendapat kedua orang calon mempelai yang akan menikah, pengadilan memberikan dispensasi kawin harus berdasarkan semangat mencegah pernikahan anak dengan pertimbangan moral, agama, adat dan budaya, aspek psikologis, aspek kesehatan, dan dampak yang ditimbulkan.2

\section{Pengertian Pernikahan Menurut Hukum Islam dan Perundang-undangan di Indonesia}

Menurut Islam perkawinan merupakan suatu perjanjian suci yang kuat dan kokoh untuk hidup bersama secara sah antara seorang laki-laki dan perempuan membentuk keluarga yang bahagia, aman, tentram, dan saling mengasihi.3

Dalam buku yang dikarang oleh Yusuf yakni:

1. Ulama Hanafiyah berpendapat, perkawinan merupakan perjanjian yang diselenggarakan untuk tujuan memperoleh kenikmatan dari wanita dengan disengaja. Maksudnya, untuk mengahalalkan seorang lelaki memperoleh kesenangan (istimtā') dari seorang wanita. Defenisi ini menghindari kerancuan dari akad jual beli (wanita), yang bermakna sebuah akad perjanjian yang dilakukan untuk memiliki budak wanita.

2. Ulama Malikiyah mendefnisikan pernikahan dengan akad perjanjian untuk menghalalkan meraih kenikmatan dengan wanita yang bukan mahram, wanita ahli kitab melalui sebuah ikrar.

3. Ulama Syafi'iyah mendefenisikan, pernikahan merupakan akad perjanjian yang mengandung unsur memperbolehkan

2 Pemerintah Republik Indonesia, "Undang-Undang Nomor 16 Tahun 2019 Tentang Perubahan Atas Undang-Undang Nomor 1 Tahun 1974 Tentang Perkawinan," Pub. L. No. 6401 (2019).

3 Sulaiman Rasyid, Fiqh Islam, (Jakarta: Attahiriyyah, 1955), 362. 
persetubuhan dengan menggunakan lafadz ankahtuka (aku menikahkanmu wahai fulan dengan fulana) atau tazawwajtu (aku mengawinkan engkau wahai fulan dengan fulanah)

4. Ulama Hanabilah mendefenisikan akad perkawinan adalah sebuah perjanjian yang didalamnya, terdapat lafazh nikah atau tazwijj atau terjemahan (dalam bahasa lan)nya yang dijadikan sebagai pedoman.4

Sama halnya dengan definisi perkawinan yang terdapat dalam UU No. 1 Tahun 1974, KHI menyebut perkawinan sebagai sebuah ikatan yang sangat kuat dan disebut juga dengan mitsaaqan ghalidzan antara suami dan istri. Di sana juga disebutkan bahwa pekawinan sebagai bentuk ketaatan menjalankan perintah Allah SWT dan bernilai ibadah.

Di dalam Pasal 1 UU No. 1 Tahun 1974 disebutkan bahwa perkawinan ialah ikatan lahir batin antara seorang pria dengan wanita sebagai suami istri dengan tujuan membentuk keluarga (rumah tangga) yang bahagia dan kekal berdasarkan Ketuhanan Yang Maha Esa.5

\section{Pengertian Dispensasi Kawin Menurut Hukum Islam dan Perundang-Undangan di Indonesia}

Dalam kontruksi hukum Islam dispensasi nikah dapat diartikan sebagai sebuah keadaan yang merubah keadaan sebuah hukum asal, misalnya dalam Islam memiliki metode mașlahah mursalah yaitu maṣlahah yang tidak ada legalitas hukumnya posisi yang tidak ada legalitas hukumnya dalam halnya mengenai makna dispensasi nikah.6

Pembatasan umur memang besar gunanya diantaranya adalah supaya kedua calon suami istri yang sudah dewasa

\footnotetext{
4 Yusuf A. Duraiwsy, Nikah Sirih Mut'ah \& Kontrak, (Jakarta: Darul Haq, 2010), 18.

5 Lembaran Negara Republik Indonesia Tahun 1974 Nomor 1.

6 Asafri Jaya Bakti, Konsep Maqasid Syari'ah al-Syatibi,(Jakarta: Raja Grafindo Persada,2002), 145.
} 
tersebut dapat memikul tanggung jawab sebagai kepala keluarga dan sebagai ibu rumah tangga.

Ditinjau dari kesehatan jiwa, setiap anak yang menjelang aqil baligh tidaklah berarti anak itu telah dewasa dan siap untuk kawin. Apalagi ditinjau dari segi psikologi anak tersebut kondisi kejiwaannya masih labil dan belum dapat dipertanggug jawabkan sebagai suami istri apalagi sebagai ayah dan ibu.

Hukum Islam menentukan tingkat kedewasaan dengan indikasi adanya kematangan jiwa yang diisyaratkan dengan ihtilāam (mimpi bersenggama) bagi anak laki-laki atau keluar darah haid bagi wanita. Apabila tanda-tanda tersebut belum keluar sampai batas usia tertentu, maka para ulama menentukan kedewasaan dengan batas usia.7

Pemahaman istilah baligh relatif berdasarkan kondisi sosial budaya dan kultur, sehingga ketentuan dewasa memasuki usia perkawinan oleh para ulama madzhab itu terakumulasi dalam empat pendapat, baik yang ditentukan dengan umur, maupun dengan tanda-tanda, yakni sebagai berikut:8

1. Ulama Syafi'iyah dan Hanabilah

Bahwa masa dewasa itu mulai umur 15 tahun. Walaupun mereka dapat menerima kedewasaan dengan tanda-tanda datang haid bagi anak perempuan dan mimpi bagi anak laki-laki, akan tetapi tanda-tanda tersebut tidak sama datangnya pada setiap orang sehingga kedewasaan ditentukan dengan standar umur. Kedewasaan antara lakilaki dan perempuan sama, karena kedewasaan ditentukan dengan akal. Dengan akal terjadi taklīf dan dengan akal pula adanya hukum.

7 Elly Surya Indah, Batas Minimal Usia Perkawinan Menurut Fiqh Empat Mazhab dan UU No.1 Tahun 1974,: (Skripsi, UIN Sunan Kalijaga, 2008), h.1516.

8 Nur Fadhilah dan Khariyati Rahmah," Rekonstruksi Batas Usia Pekawinan Anak Dalam Hukum Nasional Indonesia," Istilah: Jurnal Syari'ah dan Hukum vol 4 Nomor 2(Juli 2012), 52. 
2. Abu Hanifah berpendapat bahwa kedewasaan itu datangnya mulai umur 19 tahun bagi laki-laki dan 17 tahun bagi perempuan.

3. Imam Malik menetapkan usia dewasa adalah 18 tahun baik laki-laki maupun perempuan. 9

Secara sederhana pengertian dispensasi nikah dapat dipahami dalam dua kata dasar dispensasi dan nikah, dalam kamus besar bahasa Indonesia arti dispensasi nikah adalah pengecualian dari aturan umum untuk suatu keadaan yang khusus pembebanan dari suatu kewajiban atau larangan, menyatakan bahwa suatu peraturan perundang-undang tidak berlaku untuk suatu hal yang khusus.

Dispensasi adalah merupakan pengecualian dari suatu aturan secara umum untuk sesuatu keadaan yang bersifat khusus, pembebasan dari suatu larangan atau kewajiban.10 Roihan A.Rasyid mengatakan makna dispensasi merupakan pemberian izin oleh Pengadilan Agama kepada calon mempelai yang belum cukup umur untuk melangsungkan pernikahan bagi pria yang umurnya belum mencapai 19 tahun dan bagi wanita yang umurnya belum mencapai 16 tahun. Dispensasi nikah diajukan oleh pihak keluarga, terutama orang tua kepada Pengadilan Agama dalam bentuk permohonan.11

C.S.T Kansil juga mengemukakan pendapat mengenai makna dispensasi. Menurutnya, dispensasi nikah merupakan penetapan yang menyatakan, bahwa suatu ketentuan peraturan memang tidak berlaku bagi kasus yang diajukan oleh seorang pemohon.12 Muhammad Kunardi dan HM Mawardi Muzammil mengemukakan, bahwa dispensasi kawin adalah

\footnotetext{
9 Abdul Qadir Audah, Al-Tasyri' Al-Jināiy Al-Islāmījuz 1, (Kairo: Dār alUrubah,1964), 602-603.

10 Sudarsono, Kamus Hukum, (Jakarta: Rineka Cipta,1992), 102.

11 Roihan A.Rasyid, Hukum Acara Peradilan Agama, (Jakarta: Raja Grafindo Pesada, 1998), 32.

12 C.S.T Kansil, Kamus Istilah Aneka Ilmu, (Jakarta: Surya Multi Grafika, 2001), 52.
} 
untuk perkawinan yang calon mempelai laki-laki atau perempuannya masih di bawah umur dan belum diperbolehkan untuk menikah sesua dengan peraturan.13

Dalam Perma No. 5 Tahun 2019 bab I ketentuan umum pasal 1 ayat (5) menyatakan dispensasi kawin adalah pemberian izin kawin oleh pengadilan kepadacalon suami/istri yang belum berusia 19 tahun untuk melangsungkan perkawinan.

Kemudian setelah Undang-undang Republik Indonesia Nomor 16 Tahun 2019 Tentang Perubahan Atas UndangUndang Nomor 1 Tahun 1974 Tentang Perkawinan, maka usia perkawinan diubah.

Ketentuan Pasal 7 diubah sehingga berbunyi sebagai berikut:

\section{Pasal 7}

(1) Perkawinan hanya diizinkan apabila pria dan wanita sudah mencapai umur 19 (Sembilanbelas) tahun.

(2) Dalam hal terjadi penyimpangan terhadap ketentuan umur sebagaimana dimaksud pada ayat (1), orang tua pihak pria dan/atau orang tua pihak wanita dapat meminta dispensasi kepada pengadilan dengan alasan sangat mendesak disertai bukti-bukti pendukung yang cukup.

(3) Pemberian dispensasi oleh pengadilan dimaksud pada ayat wajib mendengarkan pendapat kedua belah calon mempelai yang akan melangsungkan perkawinan.

Ketentuan-ketentuan mengenai keadaan seorang atau kedua orang tua calon mempelai sebagaimana dimaksud

13 Muhammad Kunardi dan HM Mawardi Muzamil,"Implikasi Dispensasi Perkawinan Terhadap Eksistensi Rumah Tangga di Pengadilan Agama Semarang, "Istilah: Jurnal Pembaharuan Hukum, Vol 1, No. 2 (Mei-Agustus 2014), 211. 
dalam Pasal 6 ayat (3) dan ayat (4) berlaku juga ketentuan mengenai permintaan dispensasi sebagaimana dimaksud pada ayat (2)dengan tidak mengurangi ketentuan sebagaimana dimaksud dalam Pasal 6 ayat (6).

\section{Kedudukan Perma}

Mahkamah Agung adalah sebuah lembaga negara yang berwenang mengadili pada tingkat kasasi, menguji peraturan perundang-undangan di bawah undang-undang terhadap undang-undang, dan mempunyai wewenang lainnya yang diberikan oleh undang-undang sebagaimana yang tertuang dalam pasal 24A ayat (1) Undang-undang Dasar 1945. Mahkamah Agung yang (disingkat MA) adalah lembaga tinggi negara dalam sistem ketatanegaraan Indonesia yang merupakan pemegang kekuasaan kehakiman bersama-sama dengan Mahkamah Konstitusi.14

Mahkamah Agung sebagai lembaga kekuasaan kehakiman mempunyai fungsi mengatur sehingga menimbulkan suatu kewenangan untuk menerbitkan Surat Edaran Mahkamah Agung dan Peraturan Mahmakah Agung (PERMA). Kewenangan Mahkamah Agung membuat Permaini, semata-mata harus dan hanya bersifat pelengkap, dalam arti Perma tersebut merupakan penyempurnaan atau pelengkap terhadap peraturan perundang-undangan yang ada. Oleh karena itu, tidak dibenarkan Mahkamah Agung untuk menerbitkan Perma yang memuat tentang kebijakan umum yang tidak memiliki sandaran dan kaitannya dengan peundang-undangan yang telah dikeluarkan DPR dan Presiden.15

14 Septiana Anipatus Shalihah, "Kedudukan Peraturan Mahkamah Agung dalam Hierarki Peraturan Perundang-Undangan di Indonesia (Studi Tentang Implementasi Perma Nomor 2 Tahun 2012 Tentang Penyesuaian Batasan Tindak Pidana Ringan dan Jumlah Denda dalam KUHP di Pengadilan Negeri Kabupaten Gresik)," (Skripsi--Universitas Islam Indonesia, 2018), 3.

15 Binsar M. Gultom, Pandangan Kritis Seorang Hakim Dalam Penegakan Hukum di Indonesia, (Jakarta: Gramedia Pustaka Utama, 2015), 14. 
Kedudukan Perma diatur dalam Pasal 79 Undangundang Nomor 14 Tahun 1985 tentang Mahmakah Agung (UU MA). Perma, berdasarkan undang-undang tersebut berperan untuk mengisi kekosongan hukum terhadap materi yang belum diatur dalam undang-undang. MA sebagai lembaga yudikatif diberikan kewenangan yang bersifat atribut untuk membentuk suatu peraturan. Kewenangan ini dibatasi dalam penyelenggaraan peradilan.

Penjelasan Pasal 79 UU MA menjelaskan, bahwa apabila dalam jalannya peradilan terdapat kekurangan atau kekosongan hukum dalam suatu hal, MA memiliki wewenang membuat peraturan untuk mengisi kekurangan atau kekosongan tersebut. Ada dua hal yang menarik dicermati dari ketentuan Pasal 79 dan penjelasannya tersebut. Pertama, terkait dalam batasan materi Perma. Batasan ini dapat dilihat dari tujuan pembentukan UU MA dalam memberikewenangan membentuk Perma. Materi Perma adalah misteri yang belum diatur dalam undang-undang. Norma ini menunjukkan pentingnya kedudukan Perma. Kedua, ruang lingkup pengaturan Perma sebatas pada penyelenggaraan peradilan yang berkaitan dengan hukum acara. Pembentukan UU MA juga sudah memberikan rambu-rambu agar materi Perma tidak mengambil materi yang seharusnya menjadi materi undang-undang. Ketiga, penjelasan Pasal 79 pada paragraf kedua antara lain menyebutkan bahwa peraturan yang dikeluarkan oleh MA dibedakan dengan peraturan yang dibentuk oleh pembentuk undang-undang. MA juga tidak dapat mencampuri dan melampaui pengaturan hak dan kewajiban warga negara. 16

Hierarki yang dimaksud dalam Undang-Undang No. 12 Tahun 2011 ini adalah perjenjangan setiap jenis peraturan perundang-undangan yang didasarkan pada asas, bahwa peraturan perundang-undangan yang lebih rendah tidakboleh

16 Nur Sholikin, "Mencermati Pembentukan Peraturan Mahkamah Agung (Perma)” Istilah: Jurnal Rechts Vinding, Vol. 6 , No. 1( Februari 2017), 1-2. 
bertentangan dengan peraturan perundang-undangan yang lebih tinggi.

Undang-Undang Nomor 12 Tahun 2011 yang telah menggantikan Undang-Undang Nomor 10 Tahun 2004Tentang Pembentukan Peraturan Perundang-Undangan menyebutkan dalam bab III pasal 7 tentang jenis, hierarki, dan materi muatan peraturan perundang-undangan yang selengkapnya berbunyi sebagai berikut:

Pasal 7

(1) Jenis dan hierarki peraturan perundanganundangan terdiri atas:

a. Undang-undang Dasar Negara Republik Indonesia 1945

b. Ketetapan Majelis Permusyawaratan Rakyat;

c. Undang-undang/ Peraturan Pemerintah Pengganti Undang-undang;

d. Peraturan Pemerintah;

e. Peaturan Presiden;

f. Peraturan Daerah Provinsi;dan

g. Peraturan Daerah Kabupaten/Kota

(2) Kekuatan hukum peraturan perundang-undangan sesuai dengan hierarki sebagaimana dimaksud ayat (1)

Dari pasal tersebut diperoleh pemahaman, bahwa peraturan Mahkamah Agung tidak termasuk kedalam susunan peraturan perundang-undangan. Namun dalam pasal selanjutnya disebutkan bahwa peraturan yang dikeluarkan oleh Mahkamah Agung diakui kebenarannya sebagaimana termaktub dalam pasal 8 Undang-Undang No. 12 Tahun 2011 Tentang Pembentukan Peraturan Perundang-Undangan.

Pasal 8

(1) Jenis peraturan perundang-undang selain sebagaimana dimaksud dalam pasal 7 ayat (1) mencakup peraturan yang ditetapkan oleh Majelis Permusyawaratan Rakyat, Dewan Perwakilan Rakyat, Dewan Perwakilan Daerah, Mahkamah 
Agung, Mahkamah konstitusi, Badan Pemeriksaan Keuangan, Komisi Yudisial, Bank Indonesia, Menteri, Badan, Lembaga, atau Komisi yang setingkat yang dibentuk dengan undang-undang atau pemerintah atas perintah undang-undang, Dewan Perwakilan Rakyat Daerah Provinsi, Gubernnur, Dewan Perwakilan Rakyat Daerah Kabupaten/Kota, Bupati/Walikota, Bupati/Walikota, Kepala Desa atau yang setingkat.

(2) Peraturan peundang-undangan sebagaimana dimaksud pada ayat (1) diakui keberadaannya dan mempunyai kekuatan hukum mengikat sepanjang diperintahkan oleh perundang-undangan yang lebih tinggi atau dibentuk berdasarkan kewenangan.

Untuk itu, beberapa jenis peraturan perundangundangan yang dibentuk oleh lembaga lain selain DPR dan Presiden sebagaimana dibentuk dalam pasal 8 ayat (1) diatas, dapat dikelompokkan dalam beberapa jenis peraturan perundang-undangan:

1. Peraturan lembaga yang mempunyai daya ikat internal saja mengikat organisasi di antaranya peraturan tata tertib lembaga, peraturan mengenai susunan organisasi dan sejenis

2. Peraturan lembaga yang sebenarnya mengikat internal, namun dalam pelaksanaanya banyak berhubungan dengan subjek-subjek lain di luar organisasi yang akan terkait bila hendak melakukan perbuatan hukum tertentu yang berkaitan dengan lembaga tersebut, diantaranya peraturan Mahkamah Konstitusi dan Peraturan Mahkamah Agung, terutama untuk berbagai peraturan mengenai pedoman beracara.

3. Peraturan lembaga yang mempunyai kekuatan mengikat umum yang lebih luas, misalnya Peraturan Bank Indonesia tentang mata uang.

Apabila melihat substansi pasal 8 ayat (2) UndangUndang No. 12 Tahun 2011 Tentang Perubahan atas UndangUndang Nomor 10 Tahun 2004 Tentang Pembentukan 
Peraturan Perundang-Undangan: "Peraturan perundangundangan sebagaimana dimaksud pada ayat (1) diakui keberadannya dan mempunyai kekuatan hukum mengikat sepanjang diperintahkan oleh peraturan perundang-undangan yang lebih tinggi atau dibentuk berdasarkan kewenangan." Dalam KUHP, yang merupakan peraturan perundang-undangan yang derajatnya lebih tinggi dari Perma sebagai upaya penyesuaian KUHP di kemudian hari.17

\section{Latar Belakang Perma Nomor 5 Tahun 2019}

1. Bahwa anak merupakan amanah dan karunia Tuhan Yang Maha Esa yang memiliki harkat dan martabat sebagai manusia seutuhnya serta memiliki hak yang sama untuk tumbuh dan berkembang;

2. Bahwa Indonesia sebagai Negara pihak dalam Convention on the Rights of the Child (Konvensi tentang Hak-hak Anak) menegaskan semua tindakan mengenai anak yang dilakukan ole lembaga-lembaga kesejahteraan sosial, negara atau swasta, pengadilan, penguasa administratif atau badan legislatif, dilaksanakan demi kepentingan terbaik bagi anak;

3. Bahwa perkawinan di izinkan bagi mereka yang telah memenuhi persyaratan usia, namun dalam keadaan tertentu pengadilan dapat memberikan dispensasi kawin sesuai peraturan perundnag-undangan;

4. Bahwa proses mengadili dispensasi kawin belum diatur secara tegas dan rinci dalam peraturan perundangundangan maka Mahkamah Agung dapat mengatur lebih lanjut hal-hal yang diperlukan bagi kelancaran penyelenggaraan peradilan;

Bahwa berdasarkan pertimbangan sebagaimana dimaksud dalam hurf a sampai huruf d, perlu menetapkan Peraturan Mahkamah Agung tentang Pedoman Mengadili Permohonan Dispensasi Kawin;

17 Ronald S. Lumbun, Perma RI Wujud Kerancuan Antara Praktik Pembagian dan Pemisahan Kekuasaan, (Jakarta: Raja Grafindo Persada, 2015), 8. 


\section{Kekuasaan Kehakiman dalam Memutuskan Suatu Perkara}

Asas kekuasaan kehakiman yang bebas dan merdeka diatur di dalam Undang-undang Dasar Negara Republik Indonesia Tahun 1945, pada pasal 24 ayat (1), berbunyi "kekuasaan kehakiman merupakan kekuasaan yang merdeka untuk menyelenggarakan peradilan guna menegakkan hukum dan keadilan." Dan pasal 1 angka 1 Undang-Undang Nomor 48 Tahun 2009, berbunyi: "kekuasaan kehakiman adalah kekuasaan Negara yang merdeka untuk menyelenggarakan peradilan guna menegakkan hukum dan keadilan berdasarkan Pancasila dan Undang-Undang Dasar Negara Republik Indonesia Tahun 1945, demi terselenggaranya negara Hukum Republik Indonesia".18

Penilaian hukum sebagai proses pemaknaan akal budi dan hati nurani manusia terhadap teks undang-undang terhadap peristiwa konkrit yang dijalankan hakim, melibatkan perspektif pemikiran dan hati nurani yang bersifat individual. Kebebasan hakim dalam menafsirkan hukum merupakan kegiatan yang bersifat individual. Kebebasan hakim sebagai ekspresi intelektual dan moral yang bersumber dari individu hakim memerlukan persyaratan kompetensi dan integritas tinggi dalam rangka menggali makna-makna tersembunyi di balik teks undang- undang.

Terdapat beberapa persyaratan untuk menjamin kompetensi dan integritas hakim agar tetap dipercaya masyarakat: pertama, sejauh mana hakim bisa bekerja dengan objektif, apakah hakim yang dikontruksikan sebagai manusia bebas (kebebasan hakim) tidak bias atau berat sebelah, dan apakah senantiasa berpihak pada kebenaran. Kedua, apakah benar hakim yang baik, secara sadar atau tidak sadar tidak akan dipengaruhi sikap prejudice, disebabkan latar belakang sosial politiknya ketika memutuskan perkara, padahal seharusnya bersikap objektif dan imparsial. Ketiga, apakah

18 Rimdan, Kekuasaan Kehakiman Pasca Amandemen Konstitusi, (Jakarta: Kencana Prenada Media Group, 2012), 50. 
sikap bias di pengaruhi cara hakim dalam memahami kedudukan dan fungsinya, karena setiap mengadili perkara akan terjadi pro dan kontra.19

Dengan adanya jaminan konstitusional tersebut, sudah seharusnya hakim menjalankan tugasnya dalam menegakkan hukum dan keadilan bebas dari segala tekanan dari pihak manapun juga, sehingga dapat memberikan putusan yang seadil-adilnya. Oleh karena itu, Wahyu Affandi menegaskan, karenanya hakim dalam menjalankan tugasnya sebagai pelaksana kekuasaan kehakiman yang merdeka harus bebas dari segala campur tangan pihak manapun juga, baik intern maupun ekstern. Sehingga hakim dapat dengan tenang memberikan putusan yang seadil-adilnya.20

Akan tetapi Sudikno Mertokusumo, tetap memberikan batasan-batasan dalam hal menjalankan kemerdekaan kekuasaan kehakiman, ia menyatakan, walaupun merdeka kekuasaan kehakiman tersebut. Hakim dalam melaksanakan wewenang judicial tidaklah mutlak sifatnya. Secara mikro, hakim dibatasi oleh Pancasila, Undang-undang Dasar 1945, Undang-undang, ketertiban umum, kesusilaan,dan perilaku atau kepentingan para pihak, sedangkan secara makro hakim dibatasi oleh sistem pemerintahan, politik, ekonomi dan sebagainya. Namun pada bagian lain Sudikno Mertokusumo menguraikan menguraikan, disadari bahwa kebebasan kehakiman, yang penyelenggaraannya diserahkan kepada badan-badan peradilan, merupakan salah satu ciri khas daripada negara hukum.21

Lebih lanjut, menurut Sudikno Mertokusumo diperlakukannya pengawasan atas kekuasaan kehakiman.

19 Jimly Assidhiqie, Lay Judges \& Hakim Ad Hoc, Studi Teoritis Mengenai Sistem Peradilan Pidana Indonesia, Uakarta: Penerbit Papas Sinar Sinanti,2009), 188.

20 Wahyu Affandi, Hakim dan Penegakan hukum. (Bandung: Alumni, 1981), 57.

21 Sudikno Mertokusumo, Hukum acara Perdata Indonesia, edisi ke-5 (Yogyakarta: Liberty, 1998), 18. 
Bentuk pengawasan untuk membatasi kebebasannya, maka putusannya harus dikoreksi. Oleh karena itu, asas peradilan yang baik (principle of good judicature) ialah adanya pengawasan dalam bentuk upaya hukum.

Dengan demikian dapat ditarik benang merahnya, bahwa kekuasaan kehakiman yang merdeka adalah mutlak adanya. Akan tetapi tetap dibatasi oleh rambu-rambu hukum yang ada. Kekuasaan kehakiman yang merdeka (independent judiciary) telah menjadi ideologi yang universal masa kini dan masa datang.22

\section{Pertimbangan Majelis Hakim di PA Lubuk Pakam dalam Menetapkan Putusan No. 0017/Pdt.P/2020.Lpk}

Menyelesaikan suatu perkara atau sengketa antara para pihak. Jadi, putusan adalah perbuatan hakim sebagai penguasa atau pejabat negara.

Suatu putusan hakim terdiri dari empat bagian, yaitu:

1. Kepala putusan;

2. Identitas para pihak;

3. Pertimbangan;

4. Amar.23

Putusan hakim juga harus memberikan pertimbangan hukum terhadap perkara yang disidangkannya. Pertimbangan hukum biasanya dimulai dengan kata-kata "Menimbang.......... dan seterusnya". Dalam pertimbangan hukum ini, hakim akan mempertimbangkan dalil gugatan, bantahan, atau eksepsi dari tergugat, serta dihubungkan dengan alat-alat bukti yang ada. Dari pertimbangan hukum, hakim menarik kesimpulan tentang terbukti atau tidaknya gugatan itu. Di sinilah argumentasi hakim dipertaruhkan dalam mengonstatir segala peristiwa yang terjadi selama persidangan berlangsung.

22 M. Yahya Harahap, Beberapa Tinjauan Mengenai Sistem Peradilan dan Penyelesaian Sengketa, ( Bandung: Citra Aditya Bhakti, 1997), 31.

23 Bambang Sugeng A.S dan Sujayadi, Pengantar Hukum Acara Perdata \& Contoh Dokumen ligitasi, (Jakarta: Kencana Prenada Media Group, 2012), 85. 
Setelah hal-hal tersebut di atas dipertimbangkan satu per satu secara kronologis, kemudian barulah ditulis dalildalil hukum syara' yang menjadi sandaran pertimbangannya. Sebaiknya diutamakan dalil yang bersumber dari al-Qur'an dan al'Hadis, baru pendapat para ulama yang termuat dalam kitab-kitab fiqh. Dalil-dalil tersebut disinkronkan satu dengan yang lain agar ada hubungan hukum dengan perkara yan disidangkan.

Dalam pertimbangan hukum juga dimuat pasal-pasal peraturan perundang-undangan yang menjadi dasar putusan itu. Dalam praktik, uraian tentang pertimbangan hukum dimuat dalam bentuk "mengingat". Contohnya mengingatpasal ayat... Peraturan Pemerintah Nomor 9 Tahun 1975 (LN. 197512) dan pasal-pasal peraturan perundang-undangan yang bersangkutan.24

Menurut keterangan Ketua Pengadilan Agama Lubuk Pakam, selain daripada keterangan yang telah penulis jelaskan di atas, juga tidak ada paksaan maupun intimidasi dalam perkara, hakim juga menetapkan demi menimbang kemaslahatan bagi pihak yang berperkara. Dimana sebagian besar pihak yang mengajukan dispensasi nikah disebabkan sudah hamil diluar nikah, termasuk perkara No.0017/Pdt.P/2020/PA.Lpk yang menjadi bahan untuk di teliti oleh penulis. 25

Permohonan dispensasi nikah, 99\% yang dikabulkan oleh hakim PA Lubuk Pakam karena sudah hamil sebelum menikah. Karena jika tidak dinikahkan dikhawatirkan terjadi percekcokan antara keluarga, dimana pihak keluarga perempuan memaksa pertanggungjawaban atas pihak lakilaki untuk segera menikahi perempuan yang dalam perkara tersebut.

24 Abdul Manan, Penerapan Hukum Acara Perdata di Lindungan Peradilan Agama, (Jakarta: Kencana Prenada Group, 2008), 295.

25 Muslim, Ketua Pengadilan Agama Lubuk Pakam, Wawancara, Lubuk Pakam, 3 Agustus 2020. 
Menurut ulama Syafi'iah, hukumnya sah menikahi wanita hamil akibat zina, baik yang menikahinya itu laki-lak yang menghamilinya maupun bukan menghamilinya. Alasannya karena wanita hamil akibat zina tidak termasuk golongan wanita yang diharamkan untuk dinikahi. Mereka juga berpendapat karena akad nikah yang dilakukann itu hukumnya sah, wanita yang dinikahi tersebut halal untuk disetubuhi walaupun ia dalam keadaan hamil.26

Dalam KHI pada Bab VIII "Kawin Hamil" pasal 53 di jelaskan bahwa:

(1) Seorang wanita hamil di luar nikah, dapat dikawinkan dengan pria yang menghamilinya.

(2) Perkawinan dengan wanita hamil yang disebut pada ayat (1) dapat dilangsungkan tanpa menunggu lebih dahulu kelahiran anaknya.

(3) Dengan dilangsungkannya perkawinan pada saat wanita hamil, tidak diperlukan perkawinan ulang setela anak yang dikandung lahir.

Ada beberapa pendapat Ulama yang mengatakan tidak sahnya pernikahan dengan wanita yang sedang hamil, penulis mengutip beberapa pendapat yang mengatakan hal demikian yakni:

1. Ulama Malikiyah berpendapat, bahwa wanita yang berzina, bak atas dasar suka sama suka atau diperkosa, hamil atau tidak, ia wajib istibra'. Bagi wanita merdeka dan tidak hamil, istibra'nya tiga kali haid, sedangkan bagi wanita budak istibra'nya cukup satu kali haid, tapi bila ia hamil, baik wanita merdeka atau wanita budak, istibra'nya sampa melahirkan. Dengan demikian, ulama Malikiyyah berpendapat, bahwa hukumnya tidak sah menikahi wanita hamil akibat zina, meskipun yang menikahi itulakilaki yang menghamilinya, apalagi jika ia bukan yang menghamilinya. Bila akad nikah tetap dilangsungkan

26 Abdul Rahman Ghozali, Fiqh Munakahat, (Jakarta: Perdana Media Group, 2008), 124. 
dalam keadaan hamil, akad nikah itu fasid dan wajib difasakh.

2. Ulama Hanabilah berpendapat bahwa hukumnya tidak sah menikahi wanita yang diketahui telah berbuat zina, baik dengan laki-laki bukan yang menzinainya terlebih lagi dengan laki-laki yang menzinainya, kecuali wanita itu telah memenuhi dua syarat berikut: pertama, telah habis masa iddahnya. Jika ia hamil iddahnya habis dengan melahirkan kandungannya. Bila akad nikah dilangsungkan dalam keadaan hamil, maka akad nikahnya tidak sah. Kedua, telah bertaubat dari perbuatan zina.27

Dalam salah satu kaidah dijelaskan bahwa manakala terjadi pertentangan antara kemafsadatan dan kemaslahatan, maka segi kemafsadatannya (kerusakannya atau larangannya) harus didahulukan untuk dihindari:

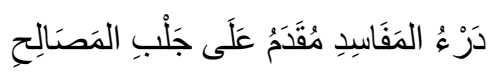

Artinya: "Menolak kerusakan harus didahulukan dari pada mendatangkan kemaslahatan".

Demi mengedepankan al-Maslahah al-Mursalah dalam kaidah ushul fiqh, yakni lebih mempertimbangkan kebaikan dan menolak kerusakan dalam kehidupan masyarakat, dan mencegah agar tidak terjadinya kemudharatan yang dikhawatirkan, maka ini menjadi salah satu pertimbangan Majlis Hakim di Pengadilan Agama Lubuk Pakam dalam menetapkan putusan dispensasi nikah.

\section{Kesesuaian Putusan No. 0017/Pdt.P/2020/Pa.Lpk dengan Perma No.5 Tahun 2019}

Setelah melakukan reset tertanggal pada 3 Agustus 2020 di Pengadilan Agama Lubuk Pakam Kelas 1 B dengan Nomor: B.726/FSH.I/PP.00.9/7/2020, penulis telah mengumpulkan data dan mewancarai salah satu pegawai Pengadilan Agama Lubuk Pakam yaitu Drs. Muslim,SH.,MA sebagai ketua dari pengadilan tersebut.

27 Memed Hamaedillah, Status Hukum Akad Nikah Wanita Hamil dan Anaknya, (Jakarta: Gema Insani Press, 2002), 37. 
Berdasarkan hasil penelitian dan wawancara penulis dengan ketua Pengadilan Agama Lubuk Pakam Kelas 1 B, bahwa hakim tidak konsisten menerapkan Perma Nomor 5 Tahun 2019 pada permohonan Dispensasi Kawin secara penuh, namun tetap mempertimbangkan beberapa hal yang tercantum dalam Perma No. 5 Tahun 2019, yaitu:

1. Pertimbangan ekonomi. Apakah sudah memiliki pekerjaan atau belum, kelayakan bagi laki-laki sebagai pemimpin rumah tangga untuk menafkahi keluarga.

2. Tidak ada paksaan terhadap pihak yang berperkara, sekalipun tidak masuk dalam putusan, tetap dalam persidangan menjadi bahan pertimbangan hakim.

Berikut beberapa point yang terdapat dalam Perma No.

5 Tahun 2019 yang belum diterapkan dalam permohonan Dispensasi Kawin pada Pengadilan Agama Lubuk Pakam Kelas 1 B, yaitu:

1. Pada Pasal 1 ayat (11) bahwa "Hakim adalah hakim tunggal pada Pengadilan Negeri dan Pengadilan Agama/Mahkamah Syari'ah". Dalam penerapannya belum diterapkan dengan keberadaan hakim tunggal pada persidangan.

2. Pada Pasal 11 ayat (2) bahwa "Hakim dan Penitera pengganti dalam memeriksa anak tidak memakai atribut persidangan". Pada penerapannya dalam persidangan Dispensasi Kawin Pengadilan Agama Lubuk Pakam belum menerapkan isi Perma No. 5 Tahun 2019 pada Pasal tersebut.

3. Pada Pasal 16h bahwa "Mempertimbangkan kondisi psikologis, sosiologis, budaya, pendidikan, kesehatan, ekonomi anak dan orang tua, berdasarkan rekomendasi dari Psikolog, Dokter/Bidan, Pekerja Sosial Profesional, Tenaga Kesejahteraan Sosial, Pusat Pelayanan Terpadu Perlindungan Perempuan dan Anak (P2TP2A) atau Komisi Perlindungan Anak Indonesia/Daerah (KPAI/KPAD)". Hakim sekalipun belum menerapkan Pasal $16 \mathrm{~h}$ tersebut dalam Putusan No.0017/Pdt.P/2020/PA.Lpk, namun tetap menanyakan tentang psikologi anak dalam bentuk nasehat. 
Seharusnya hakim dalam menetapkan permohonan Disepensasi Kawin sudah sepenuhnya menerapkan Perma No.5 Tahun 2019 sebagai bentuk hakim taat azas, sepanjang tidak dijalankan maka putusan tidak bernilai, namun seorang hakim memiliki hak imunitas, di mana hak imunitas dipandang lebih tinggi dari apapun. Bahwa putusan hakim dianggap benar sepanjang tidak ada putusan yang lebih tinggi yang dapat membatalkannya. Dan dalam Perma No. 5 Tahun 2019 tersebut tidak terdapat aturan peralihan, artinya tidak terdapat keharusan bagi hakim, hakim wajib memeriksa, mengadili, dan menyelesaikan permohonan Dispensasi Hukum mengikuti Perma No.05 Tahun 2019, sekiranya tidak mengikuti Perma tersebut maka putusan batal demi hukum.

\section{Penutup}

Pertimbangan atau sering disebut juga considerans merupakan dasar pada putusan. Pertimbangan ini terdiri dari dua, yaitu pertimbangan tentang duduknya perkara dan petimbangan tentang hukumannya. Apa yang dimuat dalam bagian pertimbangan dari putusan tidak lain adalah alasanalasan hakim sebagai pertanggungjawaban kepadamasyarakat mengapa ia sampai mengambil putusan demikian, sehingga oleh karenanya mempunyai nilai objektif. Alasan sebagai putusan harus dimuat dalam pertimbangan putusan (Pasal 184 HIR, 195 RBg). Di samping itu, Pasal 178 ayat (1) HIR dan Pasal 189 ayat (1) RBg, mewajibkan hakim karena jabatannya melengkapi segala alasan hukum yang tidak dikemukakan oleh para pihak. Lebih lanjut Mahkamah Agung berpendapat, bahwa putusan yang tidak lengkap atau kurang cukup dipertimbangkan (onvoldoende gemotiveerd) merupakan alasan untuk kasasi dan harus di batalkan (Putusan MARI No. 492 K/Sip/1970). Putusan hakim juga harus memberikan pertimbangan hukum terhadap perkara yang disidangkannya. Pertimbangan hukum biasanya dimulai dengan kata-kata "Menimbang.......... Dan seterusnya". Dalam pertimbangan hukum ini hakim akan 
mempertimbangkan dalil gugatan, bantahan, atau eksepsi dari tergugat, serta dihubungkan dengan alat-alat bukti yang ada. Dari pertimbangan hukum hakim menarik kesimpulan tentang terbukti atau tidaknya gugatan itu. Di sinilah argumentasi hakim dipertaruhkan dalam mengonstatir segala peristiwa yang terjadi selama persidangan berlangsung. Setelah hal-hal tersebut di atas dipertimbangkan satu per satu secara kronologis, kemudian barulah ditulis dalil-dalil hukum syara' yang menjadi sandaran pertimbangannya. Sebaiknya diutamakan dalil yang bersumber dari al-Qur'an dan al'Hadis, baru pendapat para ulama yang termuat dalam kitab-kitab fiqh. Dalil-dalil tersebut disinkronkan satu dengan yang lain agar ada hubungan hukum dengan perkara yan disidangkan. Dalam pertimbangan hukum juga dimuat pasal-pasal peraturan perundang-undangan yang menjadi dasar putusan itu. Dalam praktik, uaraian tentang pertimbangan hukum dimuat dalam bentuk "mengingat". Contohnya mengingat pasal ayat... Peraturan Pemerintah Nomor 9 Tahun 1975 (LN. 1975-12) dan pasal-pasal peraturan perundangundangan yang bersangkutan. Menurut keterangan Ketua Pengadilan Agama Lubuk Pakam, selain daripada keterangan yang telah penulis jelaskan di atas, juga tidak ada paksaan maupun intimidasi dalam perkara, hakim juga menetapkan demi menimbang kemaslahatan bagi pihak yang berperkara. Dimana sebagian besar pihak yang mengajukan dispensasi nikah disebabkan sudah hamil diluar nikah, termasuk perkara No.0017/Pdt.P/2020/PA.Lpk yang menjadi bahan untuk di teliti oleh penulis.

Berdasarkan hasil penelitian dan wawancara penulis dengan ketua Pengadilan Agama Lubuk Pakam Kelas 1 B bahwa hakim tidak konsisten menerapkan Perma Nomor 5 Tahun 2019 pada permohonan Dispensasi Kawin secara penuh, namun tetap mempertimbangkan beberapa hal yang tercantum dalam Perma No. 5 Tahun 2019. 


\section{Daftar Pustaka}

A. Duraiwsy, Yusuf. Nikah Sirih Mut'ah \& Kontrak. Jakarta: Darul Haq, 2010.

A. Rasyid, Roihan. Hukum Acara Peradilan Agama. Jakarta: Raja Grafindo Pesada, 1998.

A. S Bambang Sugeng dan Sujayadi. Pengantar Hukum Acara Perdata \& Contoh Dokumen ligitasi. Jakarta: Kencana Prenada Media Group, 2012.

Affandi, Wahyu. Hakim dan Penegakan hukum. Bandung: Alumni, 1981.

Asshiddiqie, Jimly. Lay Judges \& Hakim Ad Hoc, Studi Teoritis Mengenai Sistem Peradilan Pidana Indonesia. Jakarta: Penerbit Papas Sinar Sinanti, 2009.

Audah, Abdul Qadīr. Al-Tashrī' Al-Jinā̄i Al-Islāmī, juz 1. Kairo: Dār al-Urubah, 1964.

Bakti, Asafri Jaya. Konsep Maqasid Syari'ah al-Syatibi. Jakarta: Raja Grafindo Persada, 2002.

Jahar, Asep Saepudin, Dkk. Hukum Keluarga Pidana \& Bisnis. Jakarta: Kencana Prenadamedia Group, 2013.

Fadhilah, Nur dan Rahmah Khairiyati. Rekonstruksi Batas Usia Pekawinan Anak dalam Hukum Nasional Indonesia," Istilah: Jurnal Syari'ah dan Hukum, Vol. 4 Nomor 2. Juli 2012.

Ghozali, Abdul Rahman. Fiqh Munakahat. Jakarta: Perdana Media Group, 2008.

Harahap, M. Yahya. Beberapa Tinjauan Mengenai Sistem Peradilan dan Penyelesaian Sengketa. Bandung: Citra Aditya Bhakti, 1997.

Hamaedillah, Memed. Status Hukum Akad Nikah Wanita Hamil dan Anaknya. Jakarta: Gema Insani Press, 2002.

Indah, Elly Surya. Batas Minimal Usia Perkawinan Menurut Fiqh Empat Mazhab dan UU No.1 Tahun 1974,: Skripsi UIN Sunan Kalijaga. (November 2008).

Kansil, C.S.T. Kamus Istilah Aneka Ilmu. Jakarta: Surya Multi Grafika, 2001.

Kunardi, Muhammad dan Muzamil, HM Mawardi. "Implikasi Dispensasi Perkawinan Terhadap Eksistensi Rumah 
Tanggi di Pengadilan Agama Semarang"Istilah: Jurnal Pembaharuan Hukum, Vol 1 Nomor 2, Mei-Agustus 2014.

Manan, Abdul. Penerapan Hukum Acara Perdata di Lindungan Peradilan Agama. Jakarta: Kencana Prenada Group, 2008.

Mertokusumo, Sudikno. Hukum acara Perdata Indonesia, edisi ke-5. Yogyakarta: Liberty, 1998.

M.Gultom, Binsar. Pandangan Kritis Seorang Hakim dalam Penegakan Hukum di Indonesia. Jakarta: Gramedia Pustaka Utama, 2015.

Rasyid, Sulaiman. Fiqh Islam. Jakarta: Attahiriyyah, 1955.

Rimdan. Kekuasaan Kehakiman Pasca Amandemen Konstitusi. Jakarta: Kencana Prenada Media Group, 2012.

Shalihah, Septiana Anipatus. "Kedudukan Peraturan Mahkamah Agung Dalam Hierarki Peraturan Perundang-Undangan Di Indonesia (Studi Tentang Implementasi Perma Nomor 2 Tahun 2012 Tentang Penyesuaian Batasan Tindak Pidana Ringan dan Jumlah Denda dalam KUHP di Pengadilan Negeri Kabupaten Gresik)," Skripsi--Universitas Islam Indonesia, 2018.

Sholikin, Nur. "Mencermati Pembentukan Peraturan Mahkamah Agung (Perma)", Istilah: Jurnal Rechts Vinding, Vol 6 Nomor 1, Februari 2017.

S. Lumbun, Ronald. Perma RI Wujud Kerancuan Antara Praktik

Pembagian dan Pemisahan Kekuasaan. Jakarta: Raja Grafindo Persada, 2015.

Sudarsono, Kamus Hukum. Jakarta: Rineka Cipta, 1992.

Pemerintah Republik Indonesia, "Undang-Undang Nomor 16

Tahun 2019 Tentang Perubahan Atas Undang-Undang

Nomor 1 Tahun 1974 Tentang Perkawinan," Pub. L. No. 6401 (2019).

Lembaran Negara Republik Indonesia Tahun 1974 Nomor 1. 